\title{
"SUN" AND “MOON” IN CELTIC AND INDO-EUROPEAN
}

\author{
RANKO MATASOVIĆ
}

\section{Reconstruction of PIE word for "sun"}

The exact reconstruction of the PIE word for "sun" has been often disputed. I have argued (Matasović 2004b) that all of the forms in IE languages can be derived from two PIE forms: the common gender (presumably masculine) *seh ${ }_{2} w \bar{o} l$ and the neuter noun which is best reconstructed as $*{ }^{*} h_{2} w o r$. The former represented the sun as the heavenly body and the mythological figure, while the other referred to it in its more abstract nature, or simply to the notion of "sunshine". The common gender noun is the only one used in the solar theonyms, such as Vedic Súrya-, or Greek Hélios. Once it is acknowledged that there were two nouns for "sun" in PIE, there is no need to postulate a heteroclitic noun with the alternation of $* l$ and $* n$; such an alternation would be without parallel in PIE, and there is, actually, no evidence for it. There was indeed a heteroclitic noun in Proto-Indo-Iranian, but it was a garden-variety heterocliton with an alternation of $* r$ and $* n$.

That neuter heteroclitic noun, *sh2wor, is preserved in Skt. svàr (súvar) n. "sun, sunshine" and OAv. huuars n. The trace of the old heteroclitic inflexion is preserved in the OAv. gen. sg. $h^{w} \partial \underline{n} g<*^{*} h_{2} w e n-s$. The archaic static inflexion of this noun was remodelled in most languages, including Vedic, where the genitive of svàr is süras. This form can be explained either from * ${ } u h_{2} r-o s$ (by laryngeal metathesis), or transformed analogically from *sh ${ }_{2} u r-o s$ by analogy with other examples where $u v$ alternated with $\bar{u}$ in Vedic, e.g. $s \bar{u}>$ suváti "pushes, sets in motion" : sūtá- "moved" (Gerasimov 2005).

The Germanic words for "sun" can all be derived from PGerm. *sunnō (e. g. Goth. sunno, $\mathrm{OE}$ sunne). They are derived from the oblique stem of the neuter noun for "sun" in PIE. The geminate can be explained if we posit the immediate proto-form $*_{s h}$ shn-sneh $_{2}$, with the suffix $*_{-s n}$ - which is very common in the PIE names for heavenly bodies (cp. Lat. lüna, and see below). The sequence *-nsn- was almost certainly reflected as $n n$ in Proto-Germanic, cp. the development of * $n \theta n>* n n(\mathrm{OHG}$ sinnan "travel" < * $\sin \theta n a n$, Goth. $\sin \theta s$ "way") and of *sn > *nn (OE twinn "double" $<* d w i s n o-$, cp. Lat. binni "twice"). The Tocharian forms, such as Toch. B swāñco "light beam" also show the stem in *-n- from the PIE heterocliton. They are difficult to account for ${ }^{1}$, but it should be noted that their primary meaning is not "sun", but "light beam, sunlight", which is more compatible with the meaning of Ved. svàr.

The common gender (masculine) noun for "sun" had the nom. sg. *seh $2 w \overline{o l}$, acc. sg. *seh ${ }_{2} w o l m$, gen. sg. *sh ${ }^{2} u l o s$ (perhaps reshaped as *suh 2 los by laryngeal metathesis already in PIE). This noun was often confused with the neuter $*_{s} h_{2} w o r$, especially in Indo-Iranian, where the change of $* l>*_{r}$ is regular.

Latin $s \bar{l} l$ can be derived regularly (see Bammesberger 1985) from *sh $h_{2} w \bar{o} l$, with the zero-grade of the root from the oblique cases. The loss of the laryngeal is presumably expected, and the development of $* s w$ - to $s$ - is regular (as in sōror < ${ }^{*}$ swesōr $)$. The same stem $\left({ }^{*} \operatorname{seh}_{2} w \bar{o} l\right)$ was presumably reshaped as ${ }^{*} s h_{2} u l$ in Baltic, whence Lith. sáule is derived regularly.

\footnotetext{
${ }^{1}$ Adams 1999 does not give any clear derivation of this noun.
} 
Gk. hếlios is derived straightforwardly from *hāwelios $<*^{*} s_{2} h_{2} w e l-($ the stem of the acc. sg.).

Slavic forms, such as OCS slbnbce, Russ. sólnce, etc., are more easily squared with

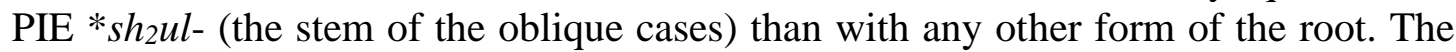
suffix $-n$ - does not have anything to do with the PIE heteroclitic suffix $*_{-} n$-; it is rather the same suffix as the suffix in měsęcb <*menns-n-ko-; the Slavic word for "sun" is thus derived from $*_{s h} u l-n$-iko-.

\section{Reconstruction of PIE word for "moon"}

The Proto-Indo-European word for "moon", on the other hand, is difficult to reconstruct unambiguously. This probably reflects the relative insignificance of the Moon in the religious belief of Indo-Europeans, in sharp contrast to its importance in the mythologies of the ancient Near East, for example. Words referring to the moon are, as a rule, substantivised adjectives denoting qualities of that heavenly body. The words for the "moon" in Indo-European languages are chiefly derived from two roots:

a) *lewk- "light": Lat. lüna, cp. also OPruss. lauxnos pl. "stars".

b) *meh ${ }_{1-}$ "to measure", cp. OCS mèsęcb, Lith. ménuo.

In several languages the meaning of words derived from this root is not "the moon", but rather "the month", i.e. the period of time lasting one lunar cycle, but this is presumably a later semantic development, cp. OIr. mí (gen. sg. mís) "a month", Lat. mensis, etc. It is difficult to reduce all of these words to a single proto-form, but the evidence points to an old masculine s-stem, *meh ${ }_{1} n \bar{o} s$, Gen. *meh ${ }_{1} n e s-s$. In a number of languages, the original oblique stem *meh ${ }_{1}$ es $-(\mathrm{cp}$. Lith. ménesio) was replaced by *meh ${ }_{1} s^{-}$, whence we get, e. g., Lat. mènsis, Gk. ménn, and OCS měsęcb. OIr. mís can also be from *meh ${ }_{1} n s>$ PCelt. *miss, with the development of *ns>-ss- which seems to be regular in Celtic (cp. OIr. gèissi "swan" (Stokes \& Strachan 1901: 2.7) < * gansi-). The same PCelt. form will explain OBret. miz, as well as Corn. mis and MW mis.

There appear to be two names of the moon in PIE: *lowksno- refers to it simply as "the shining one", because *lowksneh 2 is the collective (nom. \& acc. pl.) form of the thematic adjective *lowksno-. This adjective is still preserved as such in Av. raoxšna"shining, brilliant" (besides raoxšna- n. "light"), and this meaning is still preserved in Gk. lýkhnos "lantern" (with the secondary zero-grade which is probably a Greek development). That we are dealing with an adjective, having full thematic paradigm, is clear from the occasional Greek nom. pl. lykhna, rather than lykhnoi. The other root, *mehinoss, means literally "the measurer", and is parallel in formation to

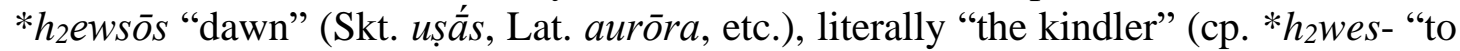
kindle", OInd. vasati).

\section{Solar deities of the insular Celts and original words for "sun" and "moon" in insular Celtic}

There can be little doubt that solar gods and/or goddesses played a prominent role in the pantheon of the Celts before Christianisation. Solar motives abound in the archaeological evidence both in Gaul and in the British Isles, and all four of the major pagan festivals, according to medieval Irish sources, took place at the equinoxes and solstices. However, written references to the solar cult among the Celts are almost non-existent, both in the classical writers and in the medieval Celtic sources. A possible exception to this claim is the following passage from St. Patrick's Epistola. 
Towards the end of his "Epistle" (\$60), the Irish saint condemns those who worship the Sun:

Nam sol iste quem uidemus ipso iubente propter nos cotidie oritur, sed numquam regnabit, neque permanebit splendor eius. Sed omnes qui adorant eum in poenam miseri male deueniant.

Yet this Sun that we see rises because of us, according to His order, but it will never reign, nor will its splendour persist. However, all those who worship it will be severely punished. (quoted from Matasović 2004a, my translation)

This passage is almost universally taken to refer to the pagan Irish, although Patrick could also have had in mind his own native Romano-British followers of the cult of Mithras, worshipped among the Roman soldiers as "Sol invictus". Be that as it may, it remains possible, even probable that the pagan Irish were Sun-worshippers.

However, the PIE word for "sun" does not mean "sun" in Irish. It rather means "an eye" (cf. OIr. súil). This change of meaning is understandable from the mythological context, in which the sun is viewed as "the eye of the sky", which is a common metaphor in the PIE poetic diction. In both Homer (Hom. hymn. 2.62) and the RigVeda (4.13.3.cd), the Sun is called a spy, or an overlooker (Skt. spáśa-, Gk. skopós); this usage of etymologically identical epithets of the (etymologically identical) word for the sun in both languages is likely to be inherited from the common IndoEuropean poetic tradition (Schmitt 1967: 163). Moreover, in the Greek tradition, the Sun is sometimes explicitly identified with the "eye of the sky" (e. g. Aristophanes, Nubes, 285: ómma aithéros). The form of OIr. súil can be derived either from the oblique stem of the PIE word for "sun", *suh $l$ - (by laryngeal metathesis), or from the nominative stem $* s h_{2} w \bar{o} l$, with the regular change of $* \bar{o}>$ PCelt. $* \bar{u}$ in the last syllable (Gerasimov 2005). In either case one must assume that it was reinterpreted as a feminine i-stem.

OIr. súil could be the same word as the name of the ancient British goddess Sulis, venerated in Aquae Sulis (now Bath). The goddess Sulis seems to have been venerated near hot springs and wells, and the connection between the concepts of the "sun", "the eye" and "the spring" also belongs to the realm of mythology ${ }^{2}$. Besides the metaphor "Sun = eye of the sky" there is also the metaphor "Well = eye of the earth", and the words for "well" are often the same as the words referring to wells, e. g. Persian čäsmä, which means both "eye" and "well", just like Croatian dial. oko. Sulis appears to have been a feminine i-stem just like OIr. súil.

The PIE name of the sun is preserved in British, cp. W. haul, OBret. houl, MBret. heuul, heul, OCorn. heuul gl. sol. The comparison with OIr. súil requires the positing of an ablauting paradigm in the PCelt. word for "sun", with the nom. sg. *sāw $\bar{u} l<$ PIE * seh $h_{2} w \bar{o} l$, and the gen. sg. *sūlos, a pattern inherited from PIE. The British languages generalised the nominative, and in Goidelic a reflex of the stem of the oblique cases is preserved, later reinterpreted as a feminine i-stem. The development of the long diphthong $* \bar{a} w$ to Proto-British $* a w$ must have preceded the otherwise regular development of $* \bar{u}>$ Brit. $* \bar{l}$ (W. $i$, Bret. $i, e$ ).

Besides haul, Welsh has another word for the sun, namely huan. This is usually taken to be from the same root as haul, and derived from something like ${ }^{*} s u\left(h_{2}\right)$ ono(LEIA: s.v. súil), or *sh ${ }_{2} u$-h $h_{3}$ ono- (with Hoffman's possessive suffix) (e.g. Gerasimov 2005). The underlying root would have been *sh $h_{2} u$ - "be warm", but there is otherwise

\footnotetext{
2 The close relationship that Sulis could have had with the sun is indicated by the Roman dedicatory formula to Sol Apollo Anicetus found at Bath.
} 
really no evidence for such a verbal root. Luvian sihwal- n., which is adduced in comparison (Rieken 1999), actually means "some sharp object", and it is derived from the adjective sihwa-, whose primary meaning is "bitter, sharp", not "warm" (Craig Melchert 1993: s.v. si(h)wal-). Thus, it remains doubtful whether it has anything in common with the PIE word for "sun". Therefore, I believe it is preferable to derive huan from another verbal root, one that is well preserved in Celtic, namely PIE *sewH- "to turn, to set in motion", from which we have OIr. soïd "turns" (PCelt. *soweti or *suweti). W. huan can be derived from PCelt. *sowono-, or, more likely, *sowon $\bar{a}^{3}$, which meant "the turning (one)", or "the moving (one)". It was an old standing epithet of the sun, envisaged as a turning wheel transversing the sky".

This etymology gains more of its plausibility if we consider the British Celtic word for the moon, which also lacks a clear PIE etymology. MW lloer (MBret. loir, loer, Corn. luir gl. luna) is usually derived from PCelt. *lugrā, and this is in turn related to PIE *lowk-, which is quite impossible in light of the lack of evidence for the root variant with $* g$ instead of $* k$. Therefore, it is preferable to derive these words from another PIE root, *lewg- "to bend, twist" (cp. Gk. lygizo "bend", lýgos "twisted branches", OE locc "lock (of hair)"). If this etymology is correct ${ }^{5}$, the noun *lugra was originally an epithet applying to the young moon, which is bent in shape. In classical mythology and poetic phraseology, the moon is sometimes identified with the bow, or with the curved horns of the moon (e. g. in Ovid, Metamorphoses, 1. 11: nec nova crescendo reparabat cornua Phoebe). Lat. lünäre means "to be bent like half moon", hence the participle lünatus "crescent-shaped". I believe it is quite conceivable that such an adjective, meaning "curved, bent, or crescent-shaped" became the British word for "moon". The derivation of PCelt. *lugrā from PIE * lugreh $_{2}$ "the twisted (one)" is straightforward, and parallel to the derivation of *lowxsna from *lowksneh ${ }_{2}$ "the shining (one)". It is quite possible that in Welsh we have preserved standing epithets rhyming with the original words for "sun" and "moon", i.e. *sowonos sāwl and *lugrā lowxsnā. Both of the epithets referred originally to the physical aspect of the two heavenly bodies.

\section{Etymology of OIr. grían "sun" and lúan "moon"}

In the meaning "sun", the inherited PIE and PCelt. word was replaced, in Old Irish, with the word grían. Old Irish grían ( $\bar{a}, \mathrm{f}$.) "sun" has not received an adequate etymological treatment so far. It is usually related to the Old Irish verb guirid, goirid "burns, warms", which is in turn a reflex of PIE * $g^{w h} e r$ - "burn" (cp., e.g., Gk. thermós "hot", OCS gorěti "burn"), but the exact proto-form of grían has remained obscure. A form such as $* g^{w h}$ reyneh $_{2}$ would be morphologically completely unmotivated $^{6}$, so the source of OIr. $i a$ is unlikely to have been the PIE diphthong *ey (as, e.g., in PIE *deywos "god" > OIr. día). It is more probable that ía < Primitive Irish *eei arose in this word by compensatory lengthening, as in OIr. géis "swan" < *geissi < *gansi (Lat. anser "goose", etc.). If so, we would have OIr. grían < ${ }^{*} g^{w} r e \overline{i s n} \bar{a}$, and this form is certainly related to W. gwres m. "heat of the sun,

\footnotetext{
${ }^{3}$ In Modern Welsh, huan is masculine, but it is both masculine and feminine in MW.

${ }^{4}$ The name of Savitár, a Vedic deity with solar connections, also appears to be derived from this root. In several Rig-Vedic hymns (e. g. RV 4.14.2, 7.63.3), savitár is actually an epithet of súrya-, the sun. 5 An alternative etymology, suggested by Schrijver (1995: 232) as "a mere possibility", is to derive MW lloer etc. from *lowsrā and relate it to Lat. lüridus "pale".

${ }^{6}$ Thurneysen 1946: 130. A similar objection would apply to a proto-form $* g^{\prime h} r e y-n \bar{a}$ (related to Russ. zorjá “dawn”), see De Bernardo Stempel 1999: 253f. and Pokorny 1959: 441f.
} 
warmth"7, Bret. groez, grouez "heat of the sun". These British words have the exact counterpart in OInd. ghramsá- m. "heat of the sun, fire", which is from PIE $* g^{w h}$ renso-, also a derivative of ${ }^{*} g^{w h} e r$ - "burn, be warm" (Pokorny 1959: 495). Both the formal and the semantic sides of the correspondence are perfect, and there can be little doubt that both words are reflexes of a single PIE etymon.

However, OIr. grís (ā, f.) "heat, fire, glow", cannot be derived from the same proto-form, because of its long $\bar{l}$. It must be from PCelt. ${ }^{*} g^{w} r \bar{\imath} s s \bar{a}<* g^{w h} r \bar{e} n s \bar{a}$, and $\mathrm{W}$. gwres must be from * $g^{w}$ resso- $<* g^{w h}$ renso-. The reflex of the root with a long vowel is also preserved in Bret. derived adjective grizias "burning, glowing" (DGVB: 180), as well as in OIr. gríssach "glowing". These differences in the vocalism are easiest to reconcile if one starts from a root-noun, nom. sg. PIE $* g^{w h}$ rêns / gen. sg. ${ }^{*} g^{w h}$ rens-os. Old Irish preserved the lengthened grade vocalism of the nominative, while Welsh and Sanskrit inherited the full grade of the oblique cases. Here we are dealing with an archaism preserved in the peripheral languages, since no traces of this root-noun have been discovered in the central IE dialects. The etymological connection of grian and gríssach was perhaps still felt by the early Irish poet who used a figura etymologica in his eulogy to Bresal Béolach:

\section{Án grían gríssach goires bréoda - Bresual}

Bresual - a bright, glowing sun, burning with splendour (Campanile 1988: ??).

However, OIr. grían cannot be directly related to this set of forms. Since *ns would have given OIr. $s(s)$, as in géis "swan" < * gansi-, grían must be from something else than PCelt. ${ }^{*} g^{w}$ rens $\bar{a}$. Moreover, ${ }^{*}$-sn- does not appear to cause compensatory lengthening, if OIr. crann "tree" is from $* k^{w} r e s n \bar{a}$ (cp. W. prenn, OE hyrst "bushes"). Therefore, we must start from a proto-form ${ }^{*} g^{w} r e n s n \bar{a}$, which would first be reflected as $* g^{w} r \bar{e} i s n \bar{a}$ in Primitive Irish. This form then developed, by assimilation, to ${ }^{*} g^{w} r \bar{e} i n \bar{a}>$ OIr. grían. The fact that OIr. grían is spelled consistently with a single - $n$ - (compared to - $n n$ - in crann) does not represent a problem, since it can be shown that the development $* C s n$ - $>-n$ - is regular, as evidenced by PCelt. *trexsno- > OIr. trén "strong", W. trech "stronger", Bret. trec'h "champion" (the PIE root is *trek-, cp. OE praka "courage"). On the other hand, it appears that *Vsn- > -nn- already in Proto-Celtic ${ }^{8}$, cp. *osno- "ash-tree" (Lat. ornus) > OIr. onn, uinnius, or *kesno- "garlic" (Russ. česnók) > OIr. cainnenn, W. (pl.) cennin "leeks, daffodils", Bret. quinghenn, quinhenn, Cornish kenin. In the few cases where OIr. preserves the cluster -sn- word-internally, comparison with other languages shows that it arose by simplification of more complex clusters, e.g. in OIr. esna, asna "rib" < PCelt. *astno$<\mathrm{PIE} * h_{2} e s t\left(h_{1}\right)-n-$, cp. W. (singulative) eisen, OInd. ásthi "bone" (gen. sg. asthnás). Thus, the derivation of grían from PCelt. $* g^{w}$ rensna $<$ PIE $* g^{w h}$ rens- $(s) n e h_{2}$ is regular.

The Celtic proto-form * $g^{w}$ rens-na "sun, heat of the sun" < PIE $* g^{w h} r e n s-n e h_{2}$ is completely analogous to Latin lüna "moon" <*lowksna $<$ PIE *lowks-neh2, which is from the root *lewk- "light", as in Latin lüx, cp. also Avestan raox̌̌na-, OPruss. lauxnos "stars", and Russ. luná (which may also be a borrowing from Latin). That is, names of the two most prominent heavenly bodies, Sun and Moon, have been derived from the root nouns * $g^{w h} r \bar{e} n s^{-}$"heat" and *lowks- "light", respectively. That the reflex

\footnotetext{
${ }^{7} \mathrm{Cp}$. also the compound baranres, with the exact parallel in OBret. baranres gl. furia (DGVB: 79), literally "rage-heat".

${ }^{8}$ See, however, Schrijver 1995: 456 against this view. Even if $*_{-}-s n->*_{-} n n$ - occurred independently in different branches of Celtic, as Schrijver believes, this would not hurt my argument.
} 
of *lowksneh $h_{2}$ existed in Celtic is clear from the existence of OIr. lúan, which is its exact reflex. This word usually occurs in the fixed expression lúan láith which means some kind of radiation from the head of a warrior (DIL: s.v. lúan). It probably originally meant "the moon", and the former meaning seems to be preserved in OIr. dé lúain "Monday", which is a calque on Lat. Lunae diess, cp. W. (dydd) Llun. The opposition *lowksneh 2 "moon" : * ${ }^{w h}$ rensneh ${ }_{2}$ "sun" may be inherited from the protolanguage, but it is also possible that only *lowksneh 2 is inherited, while $* g^{w h}$ rensneh $_{2}$ $>{ }^{*} g^{w} r e n s-n \bar{a}$ is an analogical formation limited to Celtic. The same suffix, ${ }^{*}-s n-$, is found in Skt. jyótsnā "moonlight" from jyot- <*dyewt-, cp. Skt. jyótis- n. "light" (Mayrhofer 1992: I 605), and, doubtlessly, Gk. selếnē "moon" <*selas-snā (cp. sélas "light").

Thus, we arrive at the following conclusion: OIr. grían is from Proto-Celtic ${ }^{*} g^{w} r e n s-n \bar{a}$, a derivative of $* g^{w}$ renso- "heat (of the sun)". PCelt. * $g^{w}$ renso- is a thematised form of the PIE root-noun * $g^{w h} r \bar{e} n s-$ "heat of the sun, sunshine", which is also reflected as OIr. grís "heat" and W. gwres "heat of the sun".

\section{Etymology of the Gaul. Grannos and its implications}

Another often-discussed problem concerns the etymology of the name of the Gaulish god Grannos. This theonym has been related to the PCelt. word for "beard", * grendo-, *grando- (OIr. grend, W. grann "chin, beard"), and interpreted as "the bearded one". However, this Gaulish god, who is usually identified with GraecoRoman Apollo, is never portrayed with a beard (cp. Delamarre 2002: 183). On the other hand, Apollo is, especially in the later stages of Graeco-Roman religion, a solar deity par excellence. The name Grannos could, in principle, be derived from a protoform * $g^{w}$ ransos (with *an-from syllabic $* n$ ), which would be parallel to $* g^{w}$ renso- $>$ W. gwres. That PCelt. *sn gave $n n$ in Gaulish appears certain from the development of PCelt. * $k^{w}$ resno- "tree" (OIr. crann) > Gaul. prenne gl. arborem grandem (Endlicher Glossary). Also, a proto-form ${ }^{*} g^{w}$ ransnos, parallel to ${ }^{*} g^{w}$ rensnā (> OIr. grian), at least does not contradict the evidence, since it is unknown how the cluster *-nsn- would have been reflected in Gaulish. However, it is possible to relate Gaul. Grannos to PIE * $g^{w h}$ er- "hot" only if one assumes that $g$ is the regular reflex of PCelt. ${ }^{*} g^{w}$ before $r$. Before vowels, PCelt. ${ }^{*} g^{w}$ regularly gives $w / \mathrm{u} / \mathrm{in}$ Gaulish, cp. PIE $* g^{w h} e d^{h}$ - "pray, beseech" (Gk. pothéo "wish") > PCelt. * $g^{w} e d-y o-$ (OIr. guidid "pray") > Gaul. uediíumí "I pray" (Chamalières). It cannot be argued that, on structural grounds, PCelt. ${ }^{*} g^{w} r>$ Gaul. $g r$ would be more probable than PCelt. $* g^{w} r>$ Gaul. $w r$-, since the onset $w r$ - is attested in Gaulish, cp. Gaul. uroica "heather" (attested in the theonym Matres Uroicae, Delamarre 2002: 329) < *wroyka (OIr. fráech, fróech). So, if we insist that Grannos is related to the OIr. word for "sun", we have to argue that PCelt. ${ }^{*} g^{w} r>$ Gaul. $g r$ is a special development, occurring before the reflexes of PCelt. ${ }^{*} g^{w}$ and $* w$ merged in Gaulish.

\section{Etymology of OIr. ésca "moon"}

Finally, the inherited word for "moon" was also replaced in Irish by the noun ésca, éscae, which is a neuter io-stem. This word is etymologically unclear; Pedersen's (1909-1913: II 19) derivation from the same root as PIE *meh ${ }_{1 n s}$ "moon" is impossible, and the postulated PCelt. etymon *emskyo- (as if from PIE *mskyo-) is completely unmotivated. The Celtic proto-form could have been $* \bar{e} s k y o-$ from PIE *h $h_{1}$ eysk-yo-. If this is correct, it appears possible to relate it to OCS iskra "spark" <

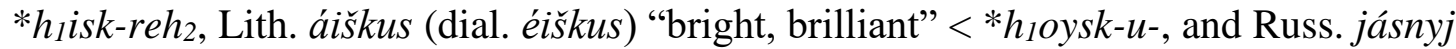
"bright" < *hioysk-no-. The root $* h_{1}$ eysk- could refer to the brightness of heavenly 
bodies, cp. Russ. dial. jáska "a bright star". In light of the semantics of the other Celtic words for "sun" and "moon" this etymology at least appears semantically wellmotivated.

\section{Conclusion}

Firstly, there were two words for "sun" in PIE, a neuter abstract noun $\left(* s h_{2}\right.$ wor $)$ and a masculine noun and theonym $\left(* \operatorname{seh}_{2} w \bar{o} l\right)$. The reconstruction of a heteroclitic noun with the alternation of $* l$ and $* n$ is both inherently improbable and unwarranted by evidence. Secondly, there are several names of sun and moon formed with the suffix $*_{-s n}$ - in early IE dialects, and two of them are preserved in Celtic:

*lowk-sneh ${ }_{2}>$ Lat. lūna, OIr. lúan, Russ. luná (?)

$*_{s} h_{2}$ un-sneh ${ }_{2}>$ Goth. sunno

$* g^{w h}$ ren-sneh ${ }_{2}>$ OIr. grían

*selas-sneh ${ }_{2}>\mathrm{Gk}$. selếnē

*dyewt-sneh ${ }_{2}>$ Skt. jyótsnā

Thirdly, in Celtic, nouns meaning sun and moon are generally derived from two types of roots: a) roots meaning "brilliance, light":

OIr. grían $<* g^{w h}$ rensneh $_{2}$

OIr. lúan $<*$ lowksneh ${ }_{2}$

OIr. escae $<* h_{1}$ eysk-yo-

W. haul $<{ }^{*} \operatorname{seh}_{2} w \bar{o} l$

b) roots referring to physical shape and/or motion of the heavenly bodies in question:

W. huan $<*^{\text {sowh }}$ ono-

W. lloer $<*$ lugreh $_{2}$

University of Zagreb

\section{BIBLIOGRAPHY}

Adams, D. Q., 1999, A Dictionary of Tocharian B (Leiden Studies in Indo-European 10), Amsterdam - Atlanta: Rodopi.

Bammesberger, A., 1985, 'Zur Bildungsweise von lat. sol', Zeitschrift für vergleichende Sprachforschung 98, 111-113.

Beekes, R. S. P., 1984, 'PIE "sun”", Münchener Studien zur Sprachwissenschaft 43, 5-8.

Campanile, E., 1988, Die älteste Hofdichtung von Leinster, Vienna: ÖAW.

Cowgill, W., 1980, 'The etymology of Irish guidid and the outcome of $* g^{w h}$ in Celtic', in: M. Mayrhofer et al., eds., Lautgeschichte und Etymologie, Wiesbaden, 49-78.

Craig Melchert, H., 1993, Cuneiform Luvian Lexicon (Lexica Anatolica, 2), Chapell Hill, N.C.

Delamarre, X., 2003, Dictionnaire de la langue gauloise, Paris: Errance.

DGVB = Fleuriot, L., 1974, Dictionnaire des gloses en vieux-breton, Paris.

DIL = Quin, E. G., ed., 1990, Dictionary of the Irish Language, Dublin: Royal Irish Academy. 
Gerasimov, I. A., 2005, 'К вопросу о рефлексах и.-е. «солнца»' [On the reflexes of the IE "sun"'], in: N. N. Kazanskij, ed., Hrdā mánasā (Сборник статей к 70-летию со дня рождения профессора Л.Г. Гериенберга), St. Petersburg: Nauka, 176-184.

Jackson, K., 1953, Language and History in Early Britain, Cambridge (Mass.): Harvard University Press.

Lambert, P.-Y., 1995, La langue gauloise, Paris: Errance.

LEIA = Vendryès, J., et al., 1959-, Lexique étymologique de l'irlandais ancien, Paris.

Lewis, H., \& Pedersen, H., 1989, A Concise Comparative Celtic Grammar, Göttingen: Vandenhoeck \& Ruprecht.

LIV = Rix, H., et al., 1998, (2 ${ }^{\text {nd }}$ ed. 2000), Lexikon der indogermanischen Verben, Wiesbaden.

Matasović, R., 2003, An Etymological Lexicon of Proto-Celtic (in progress), http://www.indo-european.nl

Matasović, R., 2004a, Sveti Patrik: Djela [St. Patrick's Epistles, with translation and commentary], Zagreb: Antibarbarus.

Matasović, R., 2004b, Gender in Indo-European, Heidelberg: Winter.

Mayrhofer, M., 1992-2000, Etymologisches Wörterbuch des Altindoarischen, Heidelberg.

McCone, K., 1996, Towards a Relative Chronology of Ancient and Medieval Celtic Sound Change, Maynooth: The Department of Old Irish, Saint Patrick's College.

McCone, K., 1996a, 'Prehistoric, Old and Middle Irish', in: K. McCone \& K. Simms, eds., Progress in Medieval Irish Studies, Maynooth: The Department of Old Irish, Saint Patrick's College, 7-54.

Pokorny, J., 1959, Indogermanisches etymologisches Wörterbuch, Bern.

Rieken, E., 1999, Untersuchungen zur nominalen Stammbildung des Hethitischen, Wiesbaden.

Schmitt, R., 1967, Dichtung und Dichtersprache in indogermanischer Zeit, Wiesbaden: Harrasssowitz.

Schrijver, P., 1995, Studies in British Celtic Historical Phonology, Leiden: Rodopi.

Stokes, W., \& Strachan, J., 1901, Thesaurus Paleohibernicus, I, London, Dublin: Cambridge University Press.

Thurneysen, R., 1946, A Grammar of Old Irish, Dublin: DIAS.

Wachter, R., 1997, 'Das indogermanische Wort für "Sonne" und die angebliche Gruppe der 1/n Heteroklitika', Historische Sprachforschung 110, 4-20. 